\title{
DAŽNAI PLAUČIŲ INFEKCINĖMIS LIGOMIS SERGANTIS VAIKAS
}

\author{
DR. VALDONE் MISEVIČIENE்
}

KMU VAIKŲ LIGŲ KLINIKA

\begin{abstract}
Reikšminiai žodžiai: vaikai, dažnos plaučių infekcinės ligos, diagnostika.
Santrauka. Ūminès ir pasikartojančios kvėpavimo takų infekcinės ligos yra dažniausia patologija vaikystėje ir viena dažniausių kreipimosi ̨ šeimos gydytoją ar pediatrą priežasčių. Vaikai dažniau serga viršutinių kvèpavimo takų ligomis, bet apie 10-30 proc. ligonių kartojasi ir apatinių kvèpavimo takų ligos. Dauguma kvèpavimo takų infekcinių ligų praeina savaime ir yra lengvos eigos. Tačiau kai kuriems vaikams jos linkusios kartotis. Gydytojui svarbu nuspręsti, kuri liga nekelia susirūpinimo ir praeis savaime, o kuri gali būti rimta, progresuojanti kvèpavimo takų patologija. Straipsnyje pateikiami literatūros duomenys apie dažniausias pasikartojančių kvẻpavimo takų infekcinių ligų priežastis bei jų diferencinę diagnostiką.
\end{abstract}

\section{IVADAS}

Üminès ir pasikartojančios kvėpavimo takų infekcinès ligos yra dažniausia vaikų patologija ir viena dažniausių kreipimosi į šeimos gydytoją ar pediatrą priežasčių. Didžiojoje Britanijoje jos lemia apie trečdali visu apsilankymu pas gydytoją ir apie 8-18 proc. skubiu stacionarizavimo atvejų [1].

Vaikai dažniau serga viršutinių kvèpavimo takų ligomis, kurias ne retai sąlygoja adenoidụ hipertrofija ar kita lètinè ausŭ, nosies, gerklès patologija. Tačiau apie $10-30$ proc. vaiku kartojasi apatinių kvėpavimo takų ligos [3].

Dauguma kvėpavimo taku infekciniu ligu praeina savaime ir yra lengvos eigos. Pagrindiniai sukélejai (apie 70-80 proc. visu atvejų) yra rino, respiracinis sincitinis, korona, gripo ir paragripo virusai. Bakterines kvėpavimo takų ligas dažniausiai sukelia pneumokokai bei kiti streptokokai, Haemofilus influnzae, Mycoplasma pneumoniae, Chlamydia pneumonia ir Moraxella catarrhalis. Mišrios kilmès infekcijos taip pat būdingos. Nustatyta, kad apie $8-30$ proc. atveju pneumoniją sukelia keliụ tipu virusai ir bakterijos arba virusų ir bakterijų deriniai. Deja, dažnai sukèlèjo iš viso nepavyksta nustatyti $[4,5]$.

Kai kuriems vaikams kvèpavimo taku infekcinès ligos linkusios kartotis: jie skundžiaji nuolatiniu arba atsinaujinančiu kosuliu, sunkesniu kvėpavimu, kartais dusuliu, skrepliavimu ar tiesiog šiaip liguista savijauta. Tokie simptomai būdingi daugeliui kvèpavimo takų ligụ, tačiau gydytojui svarbu nuspręsti, kuri liga nekelia susirūpinimo ir praeis savaime, o kuri gali būti rimta, progresuojanti kvejpavimo takų patologija. Norint tai nustatyti, labai svarbu ivertinti ligos eigą ir sunkumo laipsnị bei surasti pasikartojančiu simptomų priežastị. Taigi privalu surinkti išsamią šeimos, gyvenimo bei ligos anamnezę, atidžiai apžiūrèti ir ištirti pacientą, numatyti galimus reikalingus tyrimus ir specialistu konsultacijas $[6,7]$.

\section{PASIKARTOJANČIŲ KVĖPAVIMO TAKŲ INFEK- CINIŲ LIGŲ DAŽNUMAS}

Daugelis tyrèjų pripažįsta, jog ūminèmis viršutinių kvèpavimo taku infekcinemis ligomis vaikai serga 6-10 kartụ per metus. Didžiausias sergamumas esti 6-12 gyvenimo ménesiais ir pradejus lankyti kolektyvą. Vyresni vaikai serga rečiau, vidutiniškai 2-4 kartus per metus. Pagal A. L. Wright Tucson 1179 naujagimiu kohortoje bendrasis sergamumas ūminèmis apatiniu kvèpavimo taku ligomis pirmaisiais gyvenimo metais buvo 33 proc., didžiausią dali sudarè üminis bronchiolitas [8]. T. H. Murphy 11 metu trukusiu populiaciniu tyrimu nustaté, kad daugiausia susirgimu apatinių kvèpavimo taku ligomis pasitaiko pirmụju gyvenimo metu paskutiniais ménesiais, ketvirtadaliu atvejų - ümine pneumonija [9]. Mažesni nei dvejų metụ vaikai net penkis kartus dažniau stacionarizuojami dèl pneumonijos nei vyresni. Berniukai dèl ne visai aiškių priežas čiu dažniau serga apatinių kvẻpavimo takŭ ligomis nei mergaitės. Taip pat dažniau serga neišnešioti kūdikiai, ypač tie, kuriems diagnozuota bronchopulmoninè displazija, arba vaikai, kurių tėvai rūko. Pasyvaus rūkymo neigiama ịtaka labiau pastebima kūdikystejje ir susijusi daugiau su motinos, o ne tẻvo rūkymu. Susirgimų ūminèmis kvẻpavimo takų infekcinèmis ligomis ypač padaugeja rudeni ir pavasari $[6,7,10]$. 
Dar 1964 metais J. H. Dingle su bendradarbiais i̇rodè, kad pasikartojančių kvėpavimo takų infekcinių ligų dažnumas priklauso nuo vaiko amžiaus, šeimos dydžio, metų laikotarpio ir sąlyčio su sergančiais vaikais kolektyve (1 ir 2 lentelès) [6]. Isspūdingiausia tai, kad kai kurie maži vaikai, neturèdami jokios kitos gretutinès patologijos, gali sirgti net iki 15-17 kartu per metus, o jų bendraamžiai sirgs tik 1 ar 2 kartus. Ir vienu, ir kitu atveju kvejpavimo takų infekcinių ligu dažnumas gali būti normalus, bet tuo įtikinti dažnai sergančių vaikų tèvus yra gana sudètinga [6]. Tokie vaikai, pasak B. K. Rubin, yra „normalūs“, tačiau „nelaimingi“, o „nelaimès“ priežastis - jų paties amžius ir aplinka. Dažniausiai jie auga ir bręsta normaliai, sunkios ekstrapulmoninès infekcijos nesikartoja, šeimoje nèra sirgusių bronchų astma ir sunkiomis plaučių bei kitų organų infekcinèmis ligomis. Fizinis tyrimas remisijos laiku būna normalus, krūtinès ląstos rentgenograma, kraujo tyrimas - be pokyčių. Viena, ką reikia padaryti, - isitikinti tuo [11].

Vis dèlto kai kuriems vaikams infekcinių kvejpavimo takų ligų kartojimąsi lemia gretutinė patologija, kuri laiku nediagnozuota gali būti grèsminga ir sukelti itvairių komplikacijų. Taigi gydytojo budrumas labai svarbu.

\section{PASIKARTOJANČIUU KVĖPAVIMO TAKUৃ IN- FEKCINIŲ LIGŲ DIFERENCINĖ DIAGNOSTIKA}

Kaip minèta, norint nustatyti pasikartojančių kvėpavimo takų infekcinių ligų priežastị, labai svarbu tiksliai ìvertinti ligonio būklę paūmèjimo ir remisijos laiku,

1 lentelè. SUSIRGIMŲ KVËPAVIMO TAKŲ INFEKCINĖMIS LIGOMIS SKAIČIUS ATSIŽVELGIANT I VAIKO AMŽIĮ (PAGAL J. H. DINGLE, G. F. BADGER, W. S. JORDAN, 1964)

\begin{tabular}{|c|c|c|}
\hline $\begin{array}{l}\text { Vaiko amžius } \\
\text { (metais) }\end{array}$ & $\begin{array}{l}\text { Vidutinis } \\
\text { susirgimų } \\
\text { skaičius per } \\
\text { metus }\end{array}$ & $\begin{array}{l}\text { Susirgimų } \\
\text { skaičius } \\
\text { (min/max) }\end{array}$ \\
\hline$<1$ & 6,7 & $0-15$ \\
\hline 1 & 8,3 & $1-17$ \\
\hline 2 & 8,1 & $0-15$ \\
\hline 3 & 7,8 & $1-15$ \\
\hline 4 & 7,6 & $2-15$ \\
\hline 5 & 7,4 & $0-18$ \\
\hline 6 & 6,2 & $0-13$ \\
\hline 7 & 6,1 & 0-18 \\
\hline 8 & 6 & $0-16$ \\
\hline 9 & 5,3 & $0-13$ \\
\hline 10 & 5,7 & $0-15$ \\
\hline 11 & 5,1 & $0-14$ \\
\hline 12 & 5 & $0-12$ \\
\hline 13 & 4,6 & $0-11$ \\
\hline 14 & 4,7 & $1-15$ \\
\hline 16 & 4,8 & $2-8$ \\
\hline$>16$ & 4,6 & $2-11$ \\
\hline
\end{tabular}

2 lentelè. SUSIRGIMU KVËPAVIMO TAKŲ INFEKCINĖMIS LIGOMIS SKAIČIUS ATSI ŽVELGIANT I ŠEIMOS DYDI (PAGAL J. H. DINGLE, G. F. BADGER, W. S. JORDAN, 1964)

\begin{tabular}{cc}
\hline Šeimos dydis & $\begin{array}{l}\text { Vidutinis susirgimu } \\
\text { skaičius per metus }\end{array}$ \\
\hline 3 & 4,5 \\
\hline 4 & 5,2 \\
\hline 5 & 5,5 \\
\hline 6 & 6,3 \\
\hline 7 & 6,7 \\
\hline 8 & 5,6 \\
\hline
\end{tabular}

nuosekliai išsiaiškinti šeimos ir gyvenimo anamnezę. Dažnai to pakaks ir sudètingesnių tyrimų nereikès.

\section{Astma}

Nepaisant pagerejjusios diagnostikos ir sukauptų žinių, neatpažinta ir nediagnozuota bronchų astma vis dar yra pagrindinè priežastis, kodèl vaikai nuolat kosti, jiems „kartojasi apatinių kvėpavimo takų infekcijos“. Jei vaikas alergiškas nuo kūdikystès, šeimoje yra narių (ypač tėvai, broliai, seserys, seneliai), sirgusių bronchų astma ar kitomis alerginèmis ligomis, o aplinkoje daug rizikos veiksnių, būtina pagalvoti apie galimą alerginị procesą. Tada kontaktas su ūminėmis kvépavimo takų infekcinèmis ligomis, šaltu oru bei kitais oro alergenais bus ne kas kita kaip kontaktas su bronchų astmos simptomus provokuojančiais veiksniais [12, 13].

Vaikų bronchų astmos diagnostika gali būti sudètinga dèl ịvairialypių šios ligos priežasčių ir skirtingų vaikų švokštimo fenotipų. Deja, nėra ir vienintelio patogenozinio tyrimo, ịrodančio esant bronchų astmą vaikams iki trejų metų [12, 14]. Sensibilizacijos patvirtinimas, broncholitikų ar uždegimą slopinančio astmos gydymo poveikis, spirometrija bei bronchų hiperreaktyvumo tyrimai, bronchų obstrukcijos epizodai, išprovokuoti alergenų bei kitų aiškių aplinkos veiksnių, be kvẻpavimo takų infekcinès ligos požymių yra tie diagnostikos kriterijai, kuriais galètų būti grindžiama bronchų astmos diagnozè. Kartais bronchų astmą lydi kita gretutinè patologija. Asimetriniai ar riboti auskultaciniai pokyčiai plaučiuose, prastas vaiko augimas ir raida, būgno lazdelių pirštai, atsikosèjimas pūlingais skrepliais leistų ittarti kitą kvėpavimo takų patologiją $[14,15]$.

\section{Poinfekcinis kosulys}

Kartais tèvai labai aiškiai nurodo, kad kosulys ar dusulys atsirado po persirgtos ūminès kvépavimo takų infekcinès ligos ir tęsiasi keletą savaičių ar mėnesių. Paprastai tai lemia Bordetella pertussis ir Mycoplasma pneumonia sukeltos infekcijos, kurios labai sutrikdo mukociliarinị klirensą ir sukelia ilgai išsilaikantị bronchų reaktyvumą. Vaikai kosti priepuoliniu kosuliu, atkosti balkšvų, skaidrių gleivių. Kosulys paprastai praeina per 2-6 mènesius [16]. Kosulys, sunkesnis alsavimas ir bronchų obstrukcija mažiems vaikams po bronchiolito gali išlikti ménesiais ir net metais. Šiu simptomų patofiziologiją lemia tam tikras imuninès 
sistemos atsakas ̨ infekciją bei sutrikdytas kvépavimo taku augimas $[17,18]$.

\section{Kvèpavimo takų svetimkūnis}

Itarti svetimkūnị kvẻpavimo takuose reikètų tada, kai išsiaiškinama, jog dažnos ligos prasidejo staiga po kažkada buvusio užspringimo. Neretai tèvai neigia paspringimą, tačiau patirtis rodo, jog, deja, ne viską galima pastebèti, todèl, kilus įtarimų, būtina atlikti diagnostinę bronchoskopiją ir tuo įsitikinti. Pasitaiko atvejų, kai svetimkūniai iš kvėpavimo takų pašalinami po kelerių metų. Kai kurie jų, ypač riešutai, sukelia labai ryškų kvėpavimo takų uždegimą ir taip skatina infekcinių ligų kartojimąsi bei bronchų obstrukciją. Nustatyta, kad net pašalinus svetimkūnį bronchoskopu gali likti ribotas uždegimas, sutrikusi plaučių funkcija ir nuolatinis kosulys [19].

\section{Lètinès pūlinès plaučiu ligos}

Tik nedaugelis dažnai kvėpavimo takų infekcinėmis ligomis sergančių vaikų produktyviai kosti nuolat ar kosulys, pūlingas skrepliavimas jiems kartojasi. Tik retam vaikui pasikartojančios pneumonijos būna užsitęsusios, sunkios eigos, nepaveikiamos ịprastinio gydymo. Jei taip yra, reikètų ịtarti lètini procesą plaučiuose, galimas igimtas ar igytas bronchektazes. Kas penktas vaikas, sergantis bronchektazine liga, skundžiasi dusuliu bei skausmu krūtinès srityje [7, 20].

Cistinė fibrozè (CF) yra dažniausia vaikų bronchektazinès ligos priežastis. Daugeliui liga pasireiškia kartotinėmis plaučių infekcinėmis ligomis jau kūdikystèje, taip pat nustatoma malabsorbcijos, kasos nepakankamumo bei fizinès raidos sutrikimo požymių. Maždaug 10-20 proc. ligonių CF pirmiausia pasireiškia mekoniniu žarnų nepraeinamumu. Kai kuriems CF diagnozuojama per naujagimių patikrą arba, atvirkščiai, pavèluotai, kai liga jau pažengusi ì priekị [21].

Pasikartojančios plaučių infekcinès ligos bei nuolatinès S. aureus, H. influenzae, o vèliau Pseudomonas aeruginosa bakteriju kolonijos kvèpavimo takuose lemia stiprų uždegimo atsaką, progresuojantị bronchų sienelių pažeidimą ir bronchektazes bei plaučių fibrozę. Tokie vaikai dažnai ir sunkiai serga, jiems ryškèja kvėpavimo funkcijos nepakankamumas. Pasitaiko ir netipinių formų, kai ligos simptomatika būna ne tokia ryški ir būdinga. Todèl anksti ịtarti ir diagnozuoti CF itin svarbu [22, 23].

Anksčiau dažna vaikų bronchektazių priežastis buvo kokliušas bei tuberkuliozè. Dabar tai gana retas reiškinys. Kitų patogenų sukelta pneumonija ar bronchiolitas, net ir sunkios eigos, iki tol sveikiems vaikams paprastai bronchektazių atsiradimo nepaskatina. Išimtis - adenoviruso 3, 4, 7 ir 21 serotipai. Kai kurie vaikai, susirgę šių serotipu sukelta pneumonija ar bronchiolitu, miršta, o 40-70 proc. formuojasi obliteracinis bronchiolitas su segmentinėmis bei skiltinėmis atelektazėmis, hiperinfliacijos požymiais ir susilpnejjusia kvėpavimo funkcija. Ketvirtadaliui jų atsiranda bronchektazių. Tokie vaikai nuolat švokščia, kosti - iš pradžiu sausu, vėliau produktyviu kosuliu, gydymas broncholitikais neveiksmingas. Panašius kvèpavimo takų pažeidimus gali sukelti sunki mikoplazminè, ypač mišri mikoplazmos ir adenovirusų infekcija $[7,24,25,26]$.

Jei po persirgtos pneumonijos sveikai atrodančiam vaikui lieka ar atsinaujina lokalūs, ypač vienpusiai pokyčiai plaučiuose, reikètų ieškoti anatominių ydų bei atmesti svetimkūnio tikimybę. Pasikartojanti pneumonija būdinga plaučių sekvestracijai, bronchų stenozei, bronchomaliacijai, tracheoezofaginei fistulei bei cistiniams dariniams plaučiuose. Galimos ir kitos kvejpavimo takų, plaučių parenchimos bei plaučių kraujagyslių sklaidos ydos. Daugeli jų padeda nustatyti kompiuterinès tomografijos, angiografijos bei magnetinio rezonanso tyrimai, svarbūs ir ịvairūs kvẻpavimo funkcijos tyrimai $[6,7,27]$.

Viena iš pasikartojančių kvėpavimo takų ligų priežasčių gali būti mukociliarinio klirenso nepakankamumas (PCD) [7]. Sveiku vaikų kvejpavimo takų epitelio mikrocilijos dirba koordinuotai ir verčia judeti gleives ryklès link, kur jos nuryjamos ir atkosimos. PCD atveju ši funkcija būna sutrikusi [28]. Apskaičiuota, kad sergamumas PCD yra 1 iš $16-20$ tūkst. [29]. Šis sutrikimas nustatomas kur kas dažniau, kai nosies epitelio nuobrūžų biopsijų elektroninè mikroskopija taikoma kartu su naujausiomis kitomis technologijomis. Deja, tokią techniką gali turèti tik dideli medicinos centrai, bet net ir tuo atveju pasitaiko gana daug klaidingai teigiamų ir klaidingai neigiamų rezultatų [28, 29].

Dažniausiai PCD paveldima autosominiu recesyviniu būdu, tačiau yra duomenų, jog už tai atsakingi tam tikri ydingi genai, kurie iki šiol dar neatrasti. Mergaitès ir berniukai serga vienodai. Paprastai vaikai, kuriems yra PCD, suserga pneumonija naujagimysteje. Galima ir atkakli tachipnejja arba nosies obstrukcija gleiviškai pūlingu sekretu. Vyresniems vaikams liga reiškiasi nuolatiniu produktyviu kosuliu, netipinès formos astma, GERL, o dar vèliau randama bronchektazių. Kadangi ši liga pažeidžia ir viršutinius kvèpavimo takus, būdinga sinusitas, lètinè pūlinga sloga bei lètinis eksudacinis otitas. Esant tipiškam Kartagenerio sindromui, pusei vaikų kartu su minètais simptomais nustatoma situs inversus ir dekstrokardija. PCD atveju gali būti igimta širdies yda, hidrocefalija ar stemplès atrezija [29].

Daugelis PCD atvejų lieka nediagnozuoti, mat nèra specifinių šios ligos simptomų, diagnostika problemiška. Tradicinis sacharino mėginys, naudojamas mukociliarinei funkcijai tirti, vaikams netinka. Ateityje galima tikètis naudos nebent iš NO matavimo iškvejpiamame ore. Sergant PCD, NO kiekis jame dažniausiai būna mažesnis nei sveikų vaikų ar sergančių bronchų astma bei ne PCD kilmès bronchektazine liga [30].

\section{Imunodeficito būklès}

Dauguma dažnai kvẻpavimo takų infekcinėmis ligomis sergančių vaikų yra sveiki, jiems nèra jokių imunodeficito būklių. Tik labai retai pagrindinè priežas- 
tis - imuninès sistemos nepakankamumas. Kartais diagnozè nustatoma per vèlai, bet kartais imuninès sistemos reikšmė pervertinama - skiriama ir vartojama įvairiausių imunostimuliatorių net neịsitikinus, ar tikrai reikia [7; 31].

Itarti imunodeficito būklę reikètų, kai [31]:

- bakterinès kvèpavimo takų infekcinès ligos kartojasi daugiau nei keturis kartus per metus;

- vaikas yra sirgęs daugiau nei viena sunkia bakterine liga (pavyzdžiui, meningitu, osteomielitu);

- sukèlejjai ir infekcijuc eiga neitprasti;

- yra neaiškios kilmès bronchektazių;

- kitos, dažnesnès galimos priežastys atmestos.

Kartais įtarti imunodeficitą jau naujagimystėje bei ankstyvoje kūdikystejje, iki 6 mẻnesių amžiaus, leidžia kai kurie požymiai: mažas kalcio kiekis kraujyje, labai mažas arba labai didelis leukocitų kiekis kraujyje, vẻlai nukritusi virkštelè, širdies yda, būdinga veido forma, diarèja, kraujingos išmatos, pneumonija, supūliavę limfmazgiai, stiprūs odos pažeidimai, opelès burnos ertmejje, nuolat sekretuojančios ausys bei svorio neaugimas [6]. Vyresniems vaikams būdingas ne tik kvèpavimo takų infekcinių ligų kartojimasis, bet ir fizinès raidos atsilikimas, limfadenopatija, splenomegalija, užkrūčio liaukos padidejimas, ịvairūs autoimuniniai ir endokrininiai sutrikimai, sunkiai gydoma grybelių infekcija [6, 7, 31]. Daugelis imunodeficito būklių paveldimos arba tiesiog turi tendenciją kartotis giminèje. Taigi nereikètų delsti atlikti imuninius tyrimus tiems, kurių anamnezė šiuo atžvilgiu teigiama, žinoma apie labai sunkių infekcijų bei mirties nuo jų atvejus giminèje [32, 33].

Imunodeficito būklè gali būti pirminè arba antrinè [31]. Nustatyta daugiau nei 70 ịvairių pirminio imunodeficito variantų. Pagal sutrikusią grandi jie skiriami i keturias pagrindines grupes ir yra susiję su $\mathrm{T}$ ląstelių, B ląstelių, fagocitozès bei komplemento sistema [7, 31]. Apie 50 proc. visų pirminio imunodeficito atvejų esti nulemti humoralinio imuniteto nepakankamumo, 20-30 proc. - mišraus humoralinio ir lasstelinio atsako sutrikimo, 18 proc. - fagocitozès ir mažiau nei 2 proc. - komplemento sistemos nepakankamumo [34]. B limfocitai yra atsakingi už humoralinio imuniteto grandi, t. y. antikūnų gamybą. Jų nepakankamumas yra dažniausia imunodeficito būklè, galimas jos svyravimas nuo visiškos agamaglobulinemijos iki minimalių ir izoliuotų, netgi kliniškai nepasireiškiančių pokyčių $[6,35]$.

Imunoglobulinų koncentracija vaikų kraujo serume ryškiausiai kinta iki 2-3 metų (1 pav.). Šiuo laikotarpiu vaikai dažnai serga labiau dèl fiziologinio imuninès sistemos nebrandumo, o ne dèl jos sutrikimo. Jiems infekcinès ligos pradeda kartotis po 4 gyvenimo mènesio, kai kraujyje sumažèja iš mamos gautų IgG kiekis. Ištyrus imunoglobulinų koncentracijas ir įtarus tam tikrų imunoglobulinų nepakankamumą, būtina atsižvelgti i vaikų amžiaus ypatumus [7, 35]. Sunki a- ar hipogamaglobulinemija pasitaiko retai. Dažniau nustatomas tik nedidelio laipsnio IgA ir IgG poklasiuc

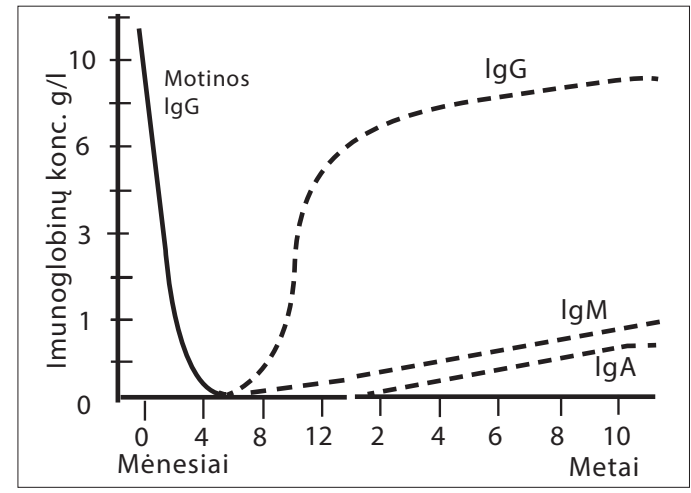

1 pav. IMUNOGLOBULINU KIEKIO KITIMAS KRAUJYJE ATSIŽVELGIANT ! VAIKO AMŽIŲ (PAGAL I. ROITT, 1989)

arba antipolisacharidinių specifinių antikūnų prieš tam tikras bakterijas nepakankamumas. Tik IgA stoka nustatoma 1 iš 400 asmenų. Vaikams tokia diagnozė neturètų būti nustatyta anksčiau nei sulaukusiems 4 metų [31, 35].

Yra keturi IgG poklasiai, kurie savo imunoglobulinų struktūra, funkcija ir koncentracija kraujo serume skiriasi. IgG1 ir IgG3 - tai antikūnai, daugiau veikiantys prieš baltymo antigenus, o IgG2 - prieš polisacharidinius antigenus, kurie yra tam tikru bakteriju kapsulès sieneleje. IgG1 ir IgG3 pradeda gamintis jau pirmaisiais gyvenimo mènesiais, o antipolisacharidiniai (IgG2) - daug véliau, veiksmingi jie tampa tik nuo dvejų metų amžiaus [7, 31]. Neretai būtent IgG2 stoka paaiškina išplitusių, neaiškios kilmès bronchektazių priežastị vaikams [36]. Nuomonès apie IgG poklasių tyrimą ir jo naudą ieškant imuninès sistemos sutrikimų vaikams skiriasi - ne visi tiriamieji, kuriems nustatomas IgG poklasių nepakankamumas, yra imlesni infekcinèms ligoms, todèl šie tyrimai atliktini, kai iš anamnezès galima daryti prielaidą, jog stokojama IgG, imuninių tyrimų duomenys visada derintini su klinika.

Ittarus imunoglobulinų stoką, atsižvelgiant ị simptomų intensyvumą, tyrimus reikètų kartoti kas 1-2 metus [31].

T limfocitai svarbų vaidmenį atlieka ne tik apsaugant organizmą nuo virusų, grybelių, mikobakterijų ir pirmuonių sukeliamų infekcinių ligų, bet ir skatinant B limfocitus gaminti imunoglobulinus [6; 35]. Pirminès $\mathrm{T}$ limfocitu stokos atvejai labai reti. Itarus $\mathrm{T}$ limfocitų stoką ar sudetingą mišrų imunodeficitą vaikams, sergantiems sunkiomis, atkakliomis ir neeilinemis infekcinemis ligomis, atliekamas limfocituc imunofenotipavimas: nustatomas $\mathrm{T}$ ir $\mathrm{B}$ limfocitu kiekis periferiniame kraujyje, ìvertinama limfocitu funkcija [6, 7 , 37]. Tyrimai atliekami tik specializuotose universitetinėse klinikose ir tik tais atvejais, kai yra daug didesniu problemų nei kvẻpavimo takų infekcinių ligų kartojimasis.

Pirminis fagocitu skaičiaus ir funkcijos sutrikimas vaikystejje labai retas, vien tik tai neturètų sąlygoti dažnų kvėpavimo takų infekcinių ligų. Tyrimuose gali būti nustatoma granuliocitopenija, paprastai ji susijusi su gydymo šalutiniu poveikiu, bet kartais gali būti atskiras 
autoimuninis reiškinys ar tam tikros autoimuninès ligos išraiška. Jei granuliocitų skaičius normalus, reikètuc tirti jų funkciją [7, 31].

Komplemento sistemos nepakankamumas gali lemti polinkị dažnai sirgti kvẻpavimo takų infekcinèmis ligomis, tačiau pirminès igimtos ydos labai retos [31].

Jei žinoma, kad šeimoje yra buvę, ar įtariama esant imunodeficito atvejų, labai svarbu tikrinti vaikus ir anksti nustatyti sunkias imunodeficito būkles, kol dar nèra negrịžtamų pokyčių plaučiuose. Identifikuoti lengvesnes formas kartais ne taip paprasta - būtinas atidus stebėjimas bei nuodugnus tyrimas. Ligonius, kuriems itariama imunodeficito būklè, būtinai turi konsultuoti klinikinis imunologas-alergologas: jis patvirtina diagnozę, skiria gydymą, numato stebèjimo planą. Kitų specialistų konsultacijos planuojamos atsižvelgiant ị vyraujančią patologiją ir kitas sąlygas.

Antrini imuninès sistemos nepakankamumą lemia neišnešiotumas, ìvairūs metaboliniai sutrikimai, infekcinès, onkologinès ir kraujo ligos, traumos bei chirurginès procedūros, prasta mityba. Pašalinus priežastị, imuninès sistemos veikla atsitaiso, buvę klinikiniai požymiai išnyksta $[6,7,31]$.

\section{APIBENDRINIMAS IR PRAKTINÉS IŠVADOS}

Svarbiausios dažno vaikų sirgimo kvẻpavimo takų infekcinėmis ligomis priežastys yra epidemiologiniai veiksniai bei anatominiai, struktūriniai kvėpavimo organų ypatumai, rečiau imuninès sistemos sutrikimai ar kita gretutinè patologija.

Gydytojas privalo nustatyti, kuris vaikas pasveiks savaime, kuriam reikia nedidelès pagalbos tik pačios virusinès ligos laiku, kuriam galbūt yra bronchų astma ar kita, daug sunkesnė negalia. Tiriant vaiką, nuolat sergantị kvėpavimo takų infekcinėmis ligomis, išskirtinis dèmesys turètų būti kreipiamas i anamnezę bei objektyvų tyrimą. Specializuoto, išsamaus ir kompleksinio tyrimo gali prireikti tik kartais. Jei vaiko fiziné raida nesutrikusi, sunki gretutinè patologija mažai tikètina. Ittarus imuninès sistemos funkcijos sutrikimą, pirmiausia reikètų tirti imunoglobulinų kiekị kraujyje. Imunodeficito diagnozę nustato ir gydymo planą sudaro gydytojas alergologas-klinikinis imunologas.

Pasikartojantis arba nuolatinis produktyvus kosulys, kai atkosima pūlingų skreplių, būdingas lètiniam procesui plaučiuose, dažniausiai bronchektazėms. Tokiais atvejais vaikus būtina siųsti pas specialistą - pulmonologą.

\section{A CHILD WITH RECURRENT RESPIRATORY INFECTIONS}

\author{
VALDONĖ MISEVIČIENE \\ DEPARTMENT OF CHILD DISEASES \\ KAUNAS UNIVERSITY OF MEDICINE
}

Key words: children, respiratory infections, diagnostics.

Summary. Recurrent respiratory infections are the commonest reason for children to be seen by their general practitioner or a paediatrician. Most infections involve only the upper respiratory tract, but in 10-30 proc. the lower respiratory tract also affected. The child with recurrent respiratory tract infections presents the clinician with a difficult diagnostic challenge. Does the child have a simply-managed cause for the symptoms, or is there evidence of a more serious underlying pathology. The article presents the literature review about the causes of recurrent infections and describes how these children should be assesed and investigated.

\section{LITERATŪRA}

1. Lung and Asthma Information Agency. The Burden of Respiratory Dis ease, Factsheet 3. London: LAIA, 1995.

2. http://epirev.oxfordjournals.org/cgi/reprint/12/1/149.pdf

3. Woroniecka $M$, Ballow $M$. Office evaluation of children with recurrent infection. Pediatr Clin North Am 2000; 47: 1211-24.

4. Heath PT. Epidemiology and bacteriology of bacterial pneumonias Pediatr Respir Rev 2000; 1: 4-7.

5. Esposito $\mathrm{S}$, Bosis $\mathrm{S}$, Faelli $\mathrm{N}$ et al. Role of atypical Bacteria and Azithromycin Therapy for children with recurrent respiratory tract infections. The pediatric Infectious Disease Journal 24 (5):438-444.

6. http://rileychildrenshospital.com/physicians/med-sub-specialties/aci/ recurrent-inf.jsp.

7. Couriel J. Assessement of the child with recurrent chest infections.Br. Med Bull. 2002; 61:115-32.

8. Wright AL, Taussig LM, Ray CG, Harrison HR, Holberg CJ. The Tuscon Children's

Respiratory Study II. Lower respiratory tract illness in the first year of life. Am J Epidemiol 1989; 129: 1232-46.

9. Murphy TH, Henderson FW, Clyde WA, Collier AM, Denny FW. Pneumonia: an eleven-year study in a pediatric practice. Am J Epidemiol 1981; 113: 12-21.

10. Li JSM, Peat JK, Xuan W, Berry G. Meta-analysis on the association between ETS exposure and the prevalence of lower respiratory tract infection in early childhood. Pediatr Pulmonol 1999; 27: 5-13.

11. Rubin BK. Evaluation of the child with recurrent chest infections. Pediat Infect Dis J 1985; 4: 88-98.

12. DTB Vol 45, No3, March, 2007.

13. Bisgaard $H$, Szeler S. Prevalence of asthma-like symptoms in young children. Pediatric Pulmonology 42: 723-728 (2007).

14. Martinez FD. Development of wheezing disorders and asthma in preschool children. Pediatrics, Vol 1009, No.2, 2002, 362-367.

15. Douglas T, Couriel JM. Differential diagnosis of asthma in children. Asthma J 2001; 6: 72-6.

16. Couriel JM. Lower respiratory tract infections in childhood. In: Ellis M. (ed) Infections of the Respiratory Tract. Cambridge: Cambridge University Press, 1998; 406-27.

17. Child HF, Couriel JM. Bronchiolitis and beyond: who will wheeze and why? Asthma J 1999; 4: 20-3.

18. Stein RT, Sherrill D, Morgan WJ et al. Respiratory syncytial virus in early life and risk of wheeze and allergy by age 13. Lancet 1999; 354: 541-5.

19. Davies H, Gordon I, Matthew DT et al. Long term follow-up after inhalation of foreign bodies. Arch Dis Child 1990; 65: 619-21.

20. Dagli E. Non cystic fibrosis bronchiectasis. Pediatr Respir Rev 2000; 1 $64-70$

21. Merelle ME, Nagelkerkere AF, Lees CM, Dezateux C. Newborn screening for cystic fibrosis//The Cochrane database of Systemic Reviews2007 issue 1. 